\title{
THE COMBINED IMPACT OF URBAN HEAT ISLAND, THERMAL BRIDGE EFFECT OF BUILDINGS AND FUTURE CLIMATE CHANGE ON THE POTENTIAL OVERWINTERING OF PHLEBOTOMUS SPECIES IN A CENTRAL EUROPEAN METROPOLIS
}

\author{
TrÁJER, A. ${ }^{1,2 *}$ - MLinÁRIK, L. ${ }^{3}$ - JUHÁsz, P. $^{3}$ - BEDE-FAZEKAS, Á. ${ }^{4}$ \\ ${ }^{1}$ University of Pannonia, Department of Limnology \\ H-8200, Veszprém, Egyetem utca 10. \\ (phone: +36-88-624-747) \\ ${ }^{2}$ MTA-PE Limnoecology Research Group \\ H-8200, Veszprém, Egyetem utca 10. \\ (phone: +36-88-624-747) \\ ${ }^{3}$ BudapestUniversity of Technology and Economics, Department of Construction Materials and \\ Engineering Geology \\ H-1111, Budapest, Müegyetem rkp. 3. K 185. \\ (phone: +36-1-463-4068) \\ ${ }^{4}$ Corvinus University of Budapest, Faculty of Landscape Architecture, Department of Garden \\ and Open Space Design \\ H-1118, Budapest, Villányi út 29-43. \\ (phone: +36-1-482-6308) \\ *Corresponding author \\ e-mail: atrajer@gmail.com \\ (Received $28^{\text {th }}$ Nov 2013; accepted $1^{\text {st }}$ Aug 2014)
}

\begin{abstract}
Leishmaniasis is one of the most important emerging vector-borne diseases in Western Eurasia. Although winter minimum temperatures limit the present geographical distribution of the vector Phlebotomus species, the heat island effect of the cities and the anthropogenic heat emission together may provide the appropriate environment for the overwintering of sand flies. We studied the climate tempering effect of thermal bridges and the heat island effect in Budapest, Hungary. Thermal imaging was used to measure the heat surplus of heat bridges. The winter heat island effect of the city was evaluated by numerical analysis of the measurements of the Aqua sensor of satellite Terra. We found that the surface temperature of thermal bridges can be at least $3-7^{\circ} \mathrm{C}$ higher than the surrounding environment. The heat emission of thermal bridges and the urban heat island effect together can cause at least $10{ }^{\circ} \mathrm{C}$ higher minimum ambient temperature in winter nights than the minimum temperature of the peri-urban areas. This milder micro-climate of the built environment can enable the potential overwintering of some important European Phlebotomus species. The anthropogenic heat emission of big cities may explain the observed isolated northward populations of Phlebotomus ariasi in Paris and Phlebotomus neglectus in the agglomeration of Budapest.
\end{abstract}

Keywords: climate change, epidemiology, Phlebotomus, sandfly, vector, leishmania, overwintering, prediction, model

\section{Introduction}

In the warm temperate and tropical areas of the World, leishmaniasis is one of the most important emerging diseases with prevalence of at least 12 million cases per year,

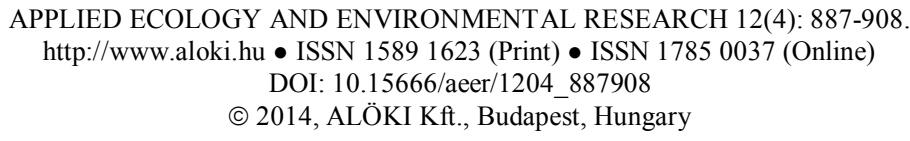


and the incidence of all clinical forms reaches 2 million new cases per year in the world (Naderer et al. 2006; WHO, 2000). The causative agents of leishmaniasis are different Leishmania protozoans (Killick-Kendrick, 1990). Two species of them have major importance in Europe: Leishmania infantum and Leishmania tropica (Ready, 2010). The main reservoir hosts of the parasites are domestic dogs (Marty et al., 2007; Shaw et al., 2003). The European Phlebotomus species and the Leishmania parasites they can transmit can be seen in Table 1. Phlebotomus mascittii Grassi (1908) has never been proven to be a vector of leishmaniasis (Naucke and Pesson, 2000).

Table 1. European Phlebotomus species, their subgenus, auctor, and the transmitted Leishmania species (Minter, 1989; Killick-Kendrick, 1990; WHO, 1984; Léger et al., 2000). The last column shows whether the species was studied in this research and if so what is the group number which the species is included in.

\begin{tabular}{|c|c|c|c|c|}
\hline Species & Subgenera & Auctor & $\begin{array}{c}\text { Transmitted } \\
\text { Leishmania } \\
\text { species }\end{array}$ & Group \\
\hline Ph. ariasi & Larroussius & Tonn. & L. infantum & 1. \\
\hline Ph. neglectus & Larroussius & Tonn. & L. infantum & 3. \\
\hline Ph. mascittii & Transphlebotomus & Grassi & - & 3. \\
\hline Ph. papatasi & Phlebotomus & Scop. & $\begin{array}{l}\text { L. donovani, } \\
\text { L. killicki, } L . \\
\text { tropica, } L . \\
\text { arabica, } L . \\
\text { major }\end{array}$ & 3. \\
\hline Ph. perfiliewi & Larroussius & Parrot & L. infantum & 3. \\
\hline Ph. perniciosus & Larroussius & Newst. & L. infantum & 2. \\
\hline Ph. sergenti & Paraphlebotomus & Parrot & $\begin{array}{l}\text { L. tropica, } L . \\
\text { major }\end{array}$ & not studied \\
\hline Ph. similis & Paraphlebotomus & Perfiliev & L. tropica & not studied \\
\hline Ph. tobbi & Larroussius & $\begin{array}{c}\text { Adler, } \\
\text { Theodor } \\
\text { et } \\
\text { Lourie }\end{array}$ & L. infantum & not studied \\
\hline
\end{tabular}

In wide urban areas of European cities the existence of a high canine seroprevalence of leishmaniasis indicates the urban presence of the parasite's vectors (Tselentis et al., 1994; Dantas-Torres, 2006). As an example, in Apulia (Italy) where Leishmania infantum is endemic, sandfly species prefer the urban environment (Tarallo et al., 2010). It is known that e.g. Phlebotomus perniciosus - one of the most important vector of Leishmania parasites in Europe - is able to colonize rural, peri-urban and urban areas (Bettini et al., 1991; Biocca et al., 1977; Maroli and Bettini, 1977). The life-cycle of $L$. infantum is distinctly peridomestic. In Portugal, it was also found that leishmaniasis cases are associated with dogs and urban areas (Cortes et al. 2007).

Many authors suggest the future expansion of vector Phlebotomus species in Europe, and according to these models Hungary will also provide adequate environment (Trájer et al., 2013). It is, however, notable that in case of Heteroptera species migration is the function of those differences which are actually existing between the temperature- 
dependent potential and the locally and historically developed number of individuals (Hufnagel and Gaál, 2005).

Climate change in Hungary (eg. according to the ENSEMBLES simulations; Pongrácz et al., 2011) is expected to change the distribution ranges of many species and even the boundaries of biomes (Bede-Fazekas, 2012; Garamvölgyi and Hufnagel, 2013). Shift of the distribution of species to north due to the global warming have been already observed (Gimesi et al., 2012).

Our aim was to explain the extrazonal occurrence of two resident Phlebotomus species in the agglomeration of Budapest by creating a model based on urban heat pollution (thermal bridges and heat island effect) and model the possible future extension of the suitable urban areas in case of different sandfly species. Our hypothesis was that urban heat pollution can allow for the overwintering of the sandflies.

\section{Review of literature}

\section{Sandflies in natural and urban areas}

In this section we attempted to collect all the relevant data on the lifestyle, nutrition and behavior of sandflies, considering their preferred environment and their connection to the built human environment. By reviewing the literature, we found references for the distribution of leishmaniasis from Brazil, South America, and four European countries, which were Italy, French, Portugal and Hungary (Budapest). Moreover, leishmaniasis was also reported by an expert committee of the WHO in 1984.

According to Bettini and Mellis (1988) the pre-imaginal stages of the sand fly species are associated with a comparatively stable, humid, cool environment, protected from rain, direct solar radiation and wind and rich in clay and organic nitrogen. Imagoes seek refuge in both anthropogenic and natural environments: e.g. inside buildings, barns, wall fissures, tree holes, animal nests (Maroli et al., 1994; Ascione et al., 1996; Maroli and Khoury, 1998). According to Moncaz et al. (2012) Phlebotomus sergenti rests and breeds inside caves and in tree nests of several rodent species. Hanson (1961) and Vanni (1940) found sand fly pupae [Phlebotomus perfiliewi, Phlebotomus major, Phlebotomus papatasi] in natural areas on the surface of fallen dead leaves and forest soil. Due to the fermentation heat of the compost, they can overwinter during cold conditions in the nature.

Human factors, travelling, and livestock are also important determinants of the abundance (Ready, 2010). In the Mediterranean parts of Europe, Phlebotomus species can also have their larval development in man-made environments - old buildings, rifts on the walls; (Killick-Kendrick, 1987a and 1987b; Naucke 2002). Supporting walls constructed with large boulders were also identified as breeding habitat for Phlebotomus sergenti although they are less important than caves. A great amount of larvae of Phlebotomus perfiliewi flies and a few larvae of Phlebotomus perniciosus were collected by Bettini et al (1986a) from a breeding site inside an abandoned cement building in Sardinia. Dantas-Torres et al. (2010) found a colony of Phlebotomus papatasi on the second floor of an old building in a highly urbanized area of Southern Italy (the old town of Bari). They found the insects near a bed and in a bathroom and potential blood sources (from e.g., pigeons and dogs) were abundant in the neighborhood. In Germany, Phlebotomus mascittii can usually be found close to human dwellings (Naucke and Pesson, 2000). Kamhawi et al. (1991) made the largest Phlebotomus collections from natural habitats, uninhabited and inhabited houses. They

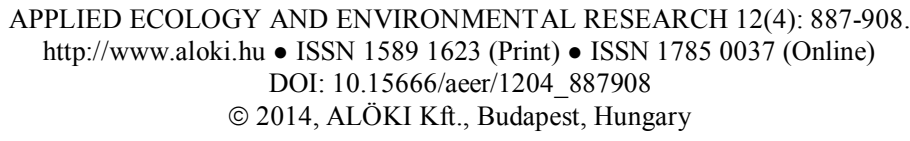


concluded that sand fly populations are able to recover, and often exceed their original natural densities in man-made artificial habitats.

\section{Phlebotomus species and leishmaniasis in Hungary}

The first observations of Phlebotomus perfiliewi in Hungary were reported from houses in Hódmezővásárhely (southwestern Hungary) in the summers of 1931-32, since the local residents noticed unusual skin symptoms related to insect biting (Szentkirályi and Lörincz 1932). Leiashmanisis can become a real emerging disease in Hungary: in 2007 and 2008 autochthonous canine leishmaniasis cases were observed in Southwestern Hungary and Budapest (Tánczos et al., 2012). Phlebotomus perfiliewi and Phlebotomus papatasi are endemic in Baranya county (Southwestern Hungary), Phlebotomus mascittii and Phlebotomus neglectus are endemic in Csongrád county (Southeastern Hungary) and in Törökbálint (a suburb of the capital), (Szentkirályi and Lörincz 1932). In contrast to the statement of Kuhn (1999), Leishmania infantum complex is not prevalent only in areas with average temperatures ranging between 5$10{ }^{\circ} \mathrm{C}$ during the coldest month (January), while in the Southwestern part of Hungary the mean temperature in January is approximately $0{ }^{\circ} \mathrm{C}$ and the canine leishmanias is prevalent in this area.

\section{The most northward observed geographical distribution of Phlebotomus species}

The known, most northward distribution of Phlebotomus neglectus observed in Europe in 2012 was Törökbálint, one of the suburbs of Budapest, at latitude $47^{\circ} 28 \mathrm{~N}$, (VBORNET, 2012), while that of Phlebotomus ariasi was in Paris (VBORNET, 2012) at latitude $48^{\circ} 51 \mathrm{~N}$. In both cases, the areas are isolated from the main, continuous distribution ranges.

\section{The studied Phlebotomus species and the abiotic factors of overwintering and activity}

We studied the potential overwintering of six Phlebotomus species (Table 1.). According to Killick-Kendrick (1987a, 1987b), the Phlebotomus species in the temperate areas of Europe can overwinter at the ontogenetic stage of $4^{\text {th }}$ instar larvae. Larvae need enough heat, humidity and organic matter to survive and develop (Naucke, 2002; Lindgren et al., 2004). The different Phlebotomus species have different minimum temperature tolerances: $-4{ }^{\circ} \mathrm{C}$ of Phlebotomus perfiliewi, Phlebotomus neglectus, Phlebotomus papatasi, Phlebotomus mascittii; $0{ }^{\circ} \mathrm{C}$ of Phlebotomus perniciosus; and $5{ }^{\circ} \mathrm{C}$ of Phlebotomus ariasi (Killick-Kendrick et al., 1984; KillickKendrick, 1999; Singh, 1999; Naucke and Schmitt, 2004). According to Lindgren et al. (2004) the preferred humidity for adults of Phlebotomus neglectus and Phlebotomus perfiliewi is between $60-80 \%$, and for Phlebotomus papatasi and Phlebotomus sergenti is below $45 \%$. While the number of days with suitable temperature for reproduction and larval growth, and moisture index have a strong correlation with the ontogeny and growth of the Phlebotomus larvae (Killick-Kendrick, 1987a; Oshagi et al., 2009), low temperatures and precipitation are expected to limit Phlebotomus distributions.

\section{Heat island effect of Budapest}

Heat island effect is an important additional climate-moderating effect, which has similar importance attenuating the winter minimum temperatures to the effect of heat 
bridges (Santamouris, 2001). The main causes of heat island effect are: increased retention of solar heat energy by open concrete and asphalt surfaces, infrared radiation, which is absorbed and reflected by photochemical smog, and the lack of shading and transpiring vegetation and evaporating wet soil surfaces (Bradley, 2007).

Urban heat island intensity depends on the size of the city (the spatial scale and the population size), the characteristics of the surface (e.g. the albedo of the surfaces, the amount of green spaces) and the natural and modified topography, the anthropogenic heat release (thermal pollution), and the prevailing wind direction (Kim et al., 2004). There is a positive correlation between the maximum heat island intensity and the order of magnitude of the population size of the settlements. The steepness of correlations shows differences in North America, Japan and Western Europe (Oke, 1973; Heinrich et al., 2006). The mean ambient temperature is increasing from the border of the populated area to the geometrical center of the city (Santamouris, 2001).

In the case of Budapest, according to the measurements of the MODIS (Moderate Resolution Imaging Spectroradiometer) multispectral sensor of satellite Aqua and the meteorological stations, the maximum difference between the downtown of the city and the Plain of Pest, which is surrounding Pest (the east part of Budapest), can be (-6)-(7) ${ }^{\circ} \mathrm{C}$ in winter nights (Pongrácz et al., 2006; Bartholy et al., 2009; Lelovics et al., 2012)

\section{The tempering effect of thermal bridges}

Female sandflies lay eggs in batches, tree holes, animal shelters, and inartificial crevices, fissures, as well as cracks of weathering construction materials which are dark and rich in organic matter (Shortt, 1930; Szentkirályi and Lőrincz 1932; Yuval, 1988). Since fissures of walls, joint gaps, foot separations interrupt the continuity of the walls and the isolations form thermal bridges. The survival of the eggs and the larvae is also dependent on the appropriate humidity and temperature of their microenvironment. If protection from excessive sun radiation and availability of organic materials are assured, thermal bridges can provide such microenvironment on buildings.

In heated buildings, temperature increases toward the interior of the building. A thermal bridge is created when materials that are poor thermal insulators come into contact, allowing heat to flow through the path of minimum thermal resistance (R-value or a material's effectiveness of resisting the conduction of heat) created, although nearby layers of material separated by airspace allow little heat transfer (Binggelli, 2010). Thermal bridges can be either integral parts of a construction or they can be generated by weathering processes. Weathering can also liberate minerals essential for microbial life, which will cause the enhancement of organic materials (Loughnan, 1969). Formation of fissures, cracks or loss of surface material occurs on the outer surface, consequently, thermal conductivity of the deteriorated parts increases. Moreover, cracks and fissures can provide "artificial micro-caves" with sufficient survival and growth conditions for the larvae, as it is described below. Furthermore, microbial activity itself accelerates the chemical weathering of the material by producing organic acids (Banfield, 1999; Drever, 1997). The presence of organic materials is essential for the colonization of the spot by the Phlebotomus larvae (Killick-Kendrick, 1987.a; Bettini, 1988). Despite the low solar radiation in the outer surface of buildings, one can observe the colonization of mosses or even little ferns in the entrance, green algae and blue bacteria.

The permanently wet surface plays the role of an absorber for the polluted air and dust (Török, 2002) which can carry organic and mineral matters which are suitable for

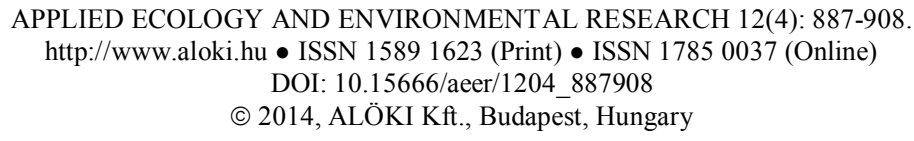


mold species. Aspergillus versicolor Vuillemin requires at least $79 \%$ moisture to grow. Besides condensation on the surfaces due to the thermal bridges, permanently wet surfaces can also contribute to the wetting of the wall by capillary absorption from the soil. Broken rain water conducting elements, such as gutters or hanging gutters, or intense seasonal precipitation wetting the walls, such as during a monsoon-period have similar effects.

Altogether, the main role of thermal bridges in the survival of larvae is that they can conduct heat and moisture to the outmost parts of the building partitions, thus creating a sufficient microenvironment for larval growth. These places are much easily accessible for the insects than interior areas.

\section{Materials and methods}

\section{The approach of the study}

According to the above detailed literature, natural refuges, such as leaf piles and artificial ones, as well, such as cracks of the buildings may be adequate habitats for sandflies and can serve as winter shelters. We aimed to study the additional heat surplus of thermal bridges (microclimatic factor) and the urban heat island effect (mesoclimatic factor), and also synthesize these effects. Thermal bridges of cracks and corners are airpolluted outdoor micro-environments where sandflies can overwinter.

\section{Thermal imaging}

We used a Testo thermometer. The camera has 845 measure points as close as $1 / 4$ inch. It displays temperature with minimum and maximum values within the same thermal image.

Not only the ambient air temperature, but also the temperature of the wall surfaces was measured, both within and outside of the thermal bridges. Since the temperatures of the warm thermal bridge and the surrounding cold wall surfaces were recorded within one thermal image, we characterized the temperature intensity of the wall surfaces, which was characterized by the measured minimum and maximum temperatures of the image.

Temperature values obtained with the Testo thermal imager may differ from the actual temperature values, thus they were calibrated with the temperature values measured on the spot with the help of a GANN Elektronik-Feuchtemesser [Nr.: 6483 Hydromette RTU 600 (sensor) IR 40 (head)] electronic thermometer.

We measured environmental temperatures in two periods, one was a colder period ( six measurements on six days between the $23^{\text {rd }}-30^{\text {th }}$ of January), the other was relatively warmer (six measurements on six days from $25^{\text {th }}$ of February to $13^{\text {rd }}$ of March). These two time periods represented average winter conditions in Budapest with average outdoor temperatures. Surface temperatures were measured in the mornings, around 7:30 $\mathrm{AM}$ and 8:00 $\mathrm{AM}$, since the morning temperatures are the lowest during the day, in general. This time the spots were shaded. During the period of measurements the sun rose between 7:21 AM (23rd of January - first day) and 6:54 AM, respectively ( $25^{\text {th }}$ February - last day). 


\section{Site of the study}

Budapest is the capital and the largest city of Hungary and also the largest city in East-Central Europe with its 1.74 million inhabitants (and with the $525 \mathrm{~km}^{2}$ area). Together with the population of the Commuter Area, the population of the urban and their suburban settlements reaches 3.3 million. (Hungarian Central Statistica, 2011). The North-South extension of Budapest is 25 and 29 kilometers in East-West direction.

In the 1960's, the fellows of the National Public Health and Medical Services observed the presence of Phlebotomus perfiliewii in the Paulin Monastery in the Gellért Hill Cave [47.486628N, 19.048276E or $47^{\circ} 29^{\prime} 5,62^{\prime \prime} \mathrm{N}, 19^{\circ} 03^{\prime} 7,66^{\prime \prime} \mathrm{E}$; the elevation from the mean see level is 235 m; (Szentkirályi and Lörincz, 1932) in Budapest, which is very close to the recent site of the study - the distance is about $700 \mathrm{~m}$. More recently, in 2009-2006 the presence of Phlebotomus neglectus and Phlebotomus mascittii were observed in Törökbálint [47.435648N, $18.915658 \mathrm{E}$ or $47^{\circ} 26^{\prime} 8.33^{\prime \prime} \mathrm{N}, 18^{\circ} 54^{\prime} 56.37^{\prime \prime}$ E]. The distance from the study area is about $12 \mathrm{~km}$ (Tánczos, 2012).

Since the 1960's, when the internal surface of the cave has been renovated by cement-based binder, we found no alive sandflies in that location. In our research, several parts of two old buildings were examined [ $\left.47^{\circ} 28^{\prime} 53^{\prime \prime} \mathrm{N}, \mathrm{k} . \mathrm{h} .19^{\circ} 03^{\prime} 19^{\prime \prime} \mathrm{E}\right]$. Both buildings are situated along the riverside of the Danube and in the proximity of Gellért Hill.

In our research, two building parts were examined of two university buildings, on two different spots. Both buildings are situated in the campus of the Budapest University of Technology and Economics, which lies on the riverside of the Danube. Two thermal bridges with a moderate-low heat intensity were selected, which can be found in many places in Budapest. It should be noted, that there are even warmer thermal bridges, but our aim was to study general spots of general buildings. One of the two spots is located on a vertical and full-height nook on the Southern facade (marked with S1), the other one in a negative building edge facing South-East (marked with S2). Spot $\mathrm{S} 1$ is situated on a brick wall facade inside a nook with varying depth between 13 and $3 \mathrm{~cm}$, and protected by a plastic gutter pipe $(\mathrm{d}=90 \mathrm{~mm})$ against the sun rays. Moreover, due to the capillary adsorption of water from the soil and wetting due to the broken gutter-pipe, spot S1 is almost always wet. This is further proved by the presence of moss colonies on the surface. Negative edge S1 has an ooidic, porous limestone cover, and it is partly shaded by a plastic gutter pipe with a diameter of $15 \mathrm{~cm}$. The appearance and the location of the two spots can be seen in Fig. 1 .

On the Spot S2 a wall rue, Asplenium ruta-muraria L. individual fern and Bryum argenteum Hedw. and green algae math were found. Asplenium ruta-muraria is a typical lithophyta, which originally lives on dry to moist, shaded limestone outcroppings, calcareous rocks (Vogel et al., 1999). The presence of this fern and the non-vascular plants indicate moisture and shading. Bryum argenteum is a common moth which can tolerate dry and sunny environments and prefers alkali soils.

Not only the surface materials, but the involved structures of the two spots are also different. Both of them are outer walls, separating heated internal spaces and environmental conditions outdoor. Spot S1 is located in a wall, whose structure is the following from the inside to the outside: $2 \mathrm{~cm}$ of color plaster on lime plaster, $44 \mathrm{~cm}$ large sized brick and $12 \mathrm{~cm}$ small-sized covering brick. The structure of the wall involving spot $\mathrm{S} 2$ is the following from the inside to the outside: $2 \mathrm{~cm}$ lime plaster, 48 $\mathrm{cm}$ large-sized brick and $25-20 \mathrm{~cm}$ porous and freshwater limestone covering. The 
Trájer et al.: The combined impact of urban heat island, thermal bridge effect of buildings and future climate change on the potential overwintering of Phlebotomus species in a Central European metropolis $-894-$

location of the spots, as well as details and layers of the wall can be seen in Fig. 2a., and Fig. $2 b$.

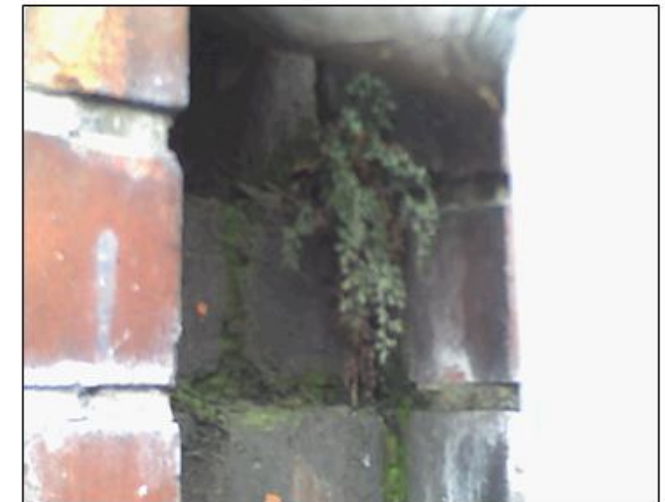

Spot S1 - brick cover and nook of the gutter

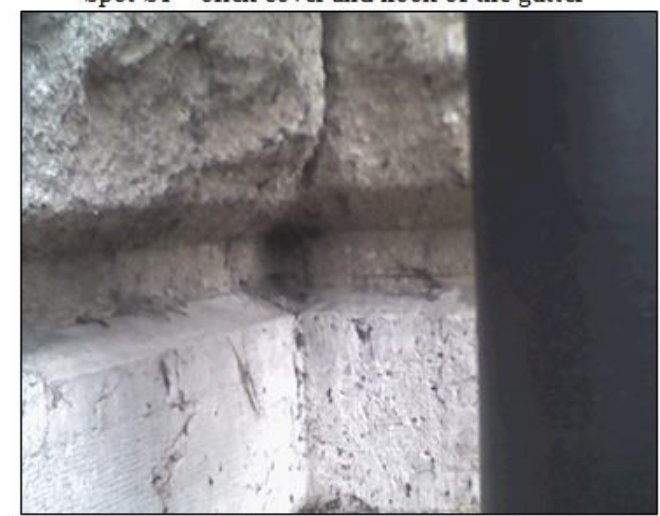

Spot S2 - Joint of porous and freshwater limestone

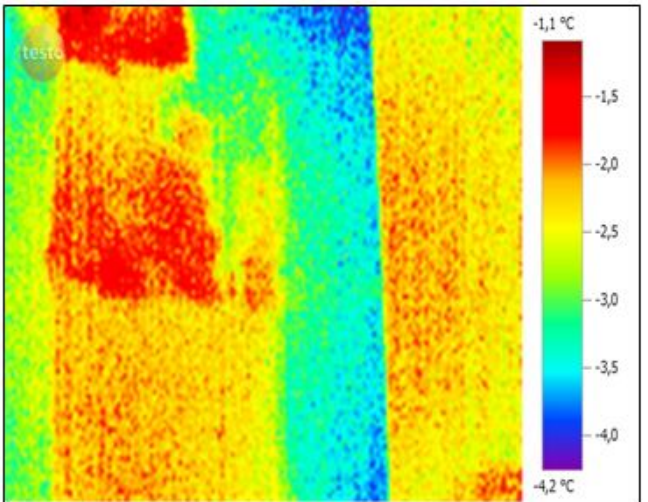

Thermal image of Spot S1

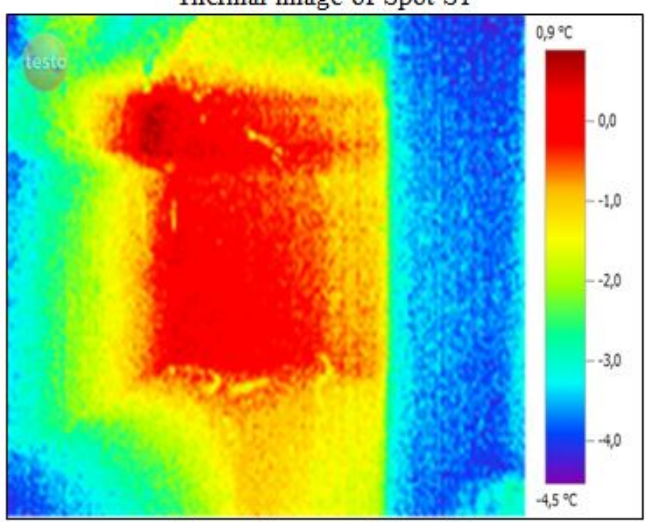

Thermal image of Spot S2

Figure 1. Appearance and thermal images of the two spots. Colors represent the temperature differences between the coldest (purple) and the warmest points (red)

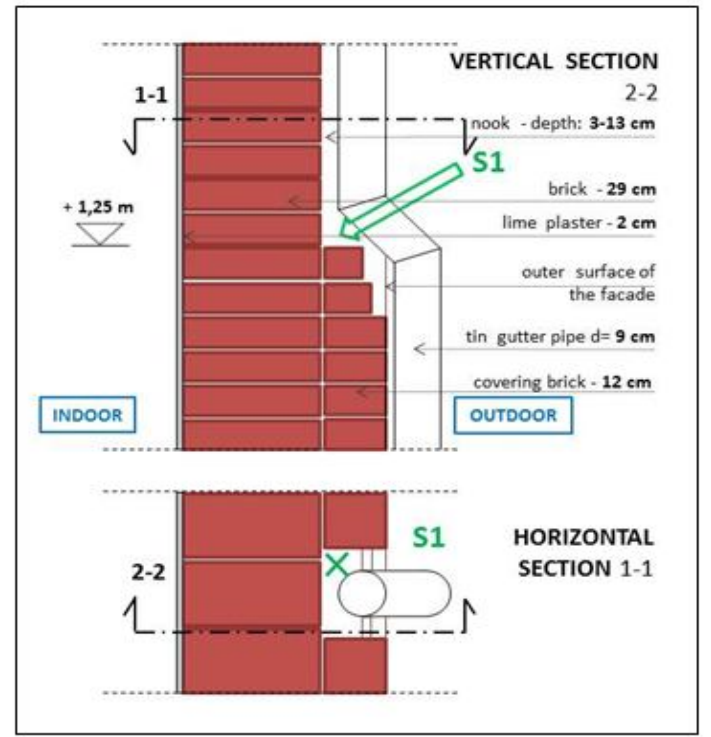

a., $\mathrm{Spot} \mathrm{S} 1$

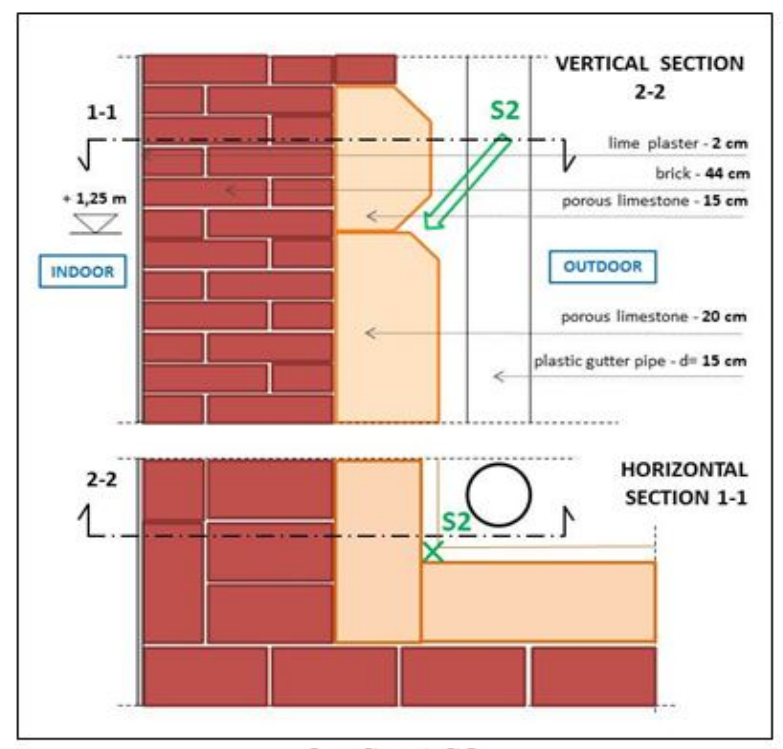

b., Spot S2

Figure 2. Details and layers of the wall structures involving spots $S 1$ and $S 2$ (marked with green arrow and green $\times$ ) 
These two spots are partly protected from weather conditions. The gutter pipes serve as a shader from solar radiation, as a wind-stopper, as well as a source of water in the case of S1 spot. Due to their orientation and location, both spots are protected from the relevant direction of the wind, which is North-West to South-East, since the Gellért Hill develops a wind-tunnel. From the Northern side both spots are protected by the buildings itself, and due to the height of the buildings, the effect of airflow is minimal. From the Southern direction $\mathrm{S} 1$ is partly protected by trees and bushes growing nearby and by the body of the gutter. S2 is protected from this direction by the Southern wing of the U-shaped building, and also by the gutter-pipe. As for protection against excessive rain-wash, both the pipes and the drips of the buildings are effective.

\section{Data sources}

\section{Climatic data of Budapest}

The ground temperature data of Budapest and its surroundings were obtained from MODIS (Moderate Resolution Imaging Spectroradiometer) sensor of the Aqua satellite of NASA (Gutro et al. 2002). The satellite has quasi-polar orbit and makes images between 02-03 UTC and between 12-13 UTC (Wan 1999). Since the colder temperatures had importance in this research, the images were obtained at night. A grid with 4900 points was selected between latitude $47.2208 \mathrm{~N}-47.7958 \mathrm{~N}$ and longitude 18.6073E-19.6740E. Between 2003-01-01 and 2008-12-31 643 images were taken which had less than $20 \%$ data absence. The 12 images which were selected among them can be seen in Fig. 3 with the urban mean temperature and the difference of urban and rural temperatures (calculated by Lelovics et al. 2011). The selected images were taken in 2007-11-29, 2007-01-27, 2005-01-24, 2003-01-16, 2008-11-23, 2003-12-07, 200702-04, 2004-12-07, 2006-12-11, 2005-11-03, 2005-04-05, and 2003-10-14 with urban mean temperatures $-6.02899,-5.91848,-3.99395,-3.88729,-1.96469,-1.9346,0.16965$, $0.31202,2.0499,2.11026,3.93641$, and $4.19791^{\circ} \mathrm{C}$, respectively.

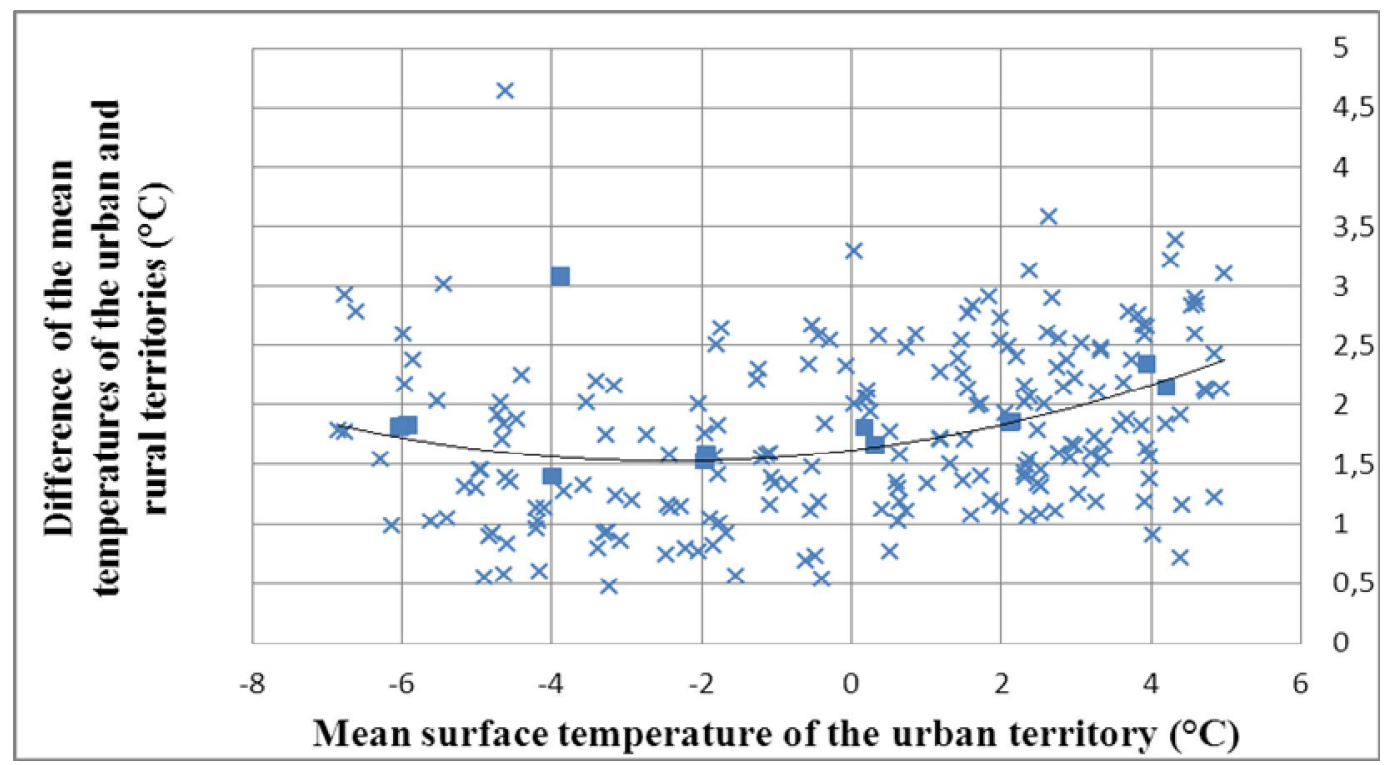

Figure 3. The difference of the mean temperatures of the urban and rural territories with a second order regression line. Only the days with less than 20\% data absence and with urban mean temperature between $-7-5{ }^{\circ} \mathrm{C}$ are displayed. The selected 12 days are marked with square symbol. 


\section{Software and statistics}

For processing the thermal images, Testo's own software, IRSoft Testo program was used. For linear regression analysis Microsoft Excel 2010 was used. R statistic analyzer and Microsoft Excel 2010 were used as data preprocessors. GIS (Geographic Information System) modeling was achieved by ESRI ArcGIS 10 software, and the output layouts were edited by Adobe Photoshop.

\section{The physical characteristics of the covering materials of the studied surfaces}

The covering material of the first thermal bridge was brick, and that of the second one was limestone. The composition of the covering material determines e.g. the $\mathrm{pH}$ of the surface, the insulation properties, the rate of water absorption and the albedo. In the present study, thermal conductivity and heat loss of the thermal bridges were considered. Firstly, thermal conductivity value and the thickness of the different layers determine the thermal gradient of the layers (Table 2). With the help of these data, the heat loss in a building element (the u-value) was calculated in $\mathrm{W} / \mathrm{m}^{2} \mathrm{~K}$. The importance of such a calculation is that temperature inside a deep crack located in an outer layer with very low thermal conductivity value can be much higher than the external temperature. Both thermal properties of the materials, as well as the facilitated calculation method used for the heat-balance were obtained from the educational material of the Building Physics courses of the Faculty of Architecture and Faculty of Civil Engineering of the Budapest University of Technology and Economics. Properties and calculated gradients of the layers are listed in Table 2.

Table 2. Detailed dimensional, quantitative and thermal properties of the layers in the wall structures of the spots $S 1$ and $S 2$

\begin{tabular}{|c|c|c|c|c|c|c|c|c|}
\hline Layers & $\begin{array}{l}\text { thick } \\
\text {-ness }\end{array}$ & $\begin{array}{c}\text { Appa- } \\
\text { rent } \\
\text { density }\end{array}$ & $\begin{array}{c}\text { Thermal } \\
\text { conduct. } \\
(\lambda)\end{array}$ & $\begin{array}{c}\text { Heat } \\
\text { transfer } \\
\text { coeff. }\end{array}$ & $\begin{array}{l}\text { Thermal } \\
\text { resistance } \\
\text { (R) }\end{array}$ & $\begin{array}{c}\text { Proportio } \\
\text { n of } \\
\text { thermal } \\
\text { resistance }\end{array}$ & $\begin{array}{c}\text { Fall of } \\
\text { temper. } \\
\text { inside } \\
\text { the } \\
\text { layer }\end{array}$ & $\begin{array}{c}\text { Fall of } \\
\text { tempe- } \\
\text { rature }\end{array}$ \\
\hline & $\mathbf{m}$ & $\mathrm{kg} / \mathrm{m}^{3}$ & $\mathbf{W} / \mathbf{m K}$ & $\mathbf{W} / \mathbf{m}^{2} \mathbf{K}$ & $\mathrm{d} / \lambda$ & $\mathrm{Ri} / \mathrm{R}$ & $\begin{array}{l}\text { at dTi-e } \\
=23 \mathrm{oC}\end{array}$ & per $\mathrm{cm}$ \\
\hline \multicolumn{9}{|c|}{ S1 } \\
\hline $\mathrm{h}_{\mathrm{e}}$ & & & & 24,000 & 0,042 & 0,060 & 1,38 & \\
\hline $\begin{array}{c}\text { Covering } \\
\text { brick }\end{array}$ & 0,12 & 1800 & 0,930 & 7,750 & 0,129 & 0,186 & 4,29 & 0,357 \\
\hline Brick wall & 0,29 & 1730 & 0,780 & 2,690 & 0,372 & 0,537 & 12,35 & 0,426 \\
\hline $\begin{array}{c}\text { Lime } \\
\text { plaster }\end{array}$ & 0,02 & 1650 & 0,810 & 40,500 & 0,025 & 0,036 & 0,82 & 0,410 \\
\hline $\mathrm{h}_{\mathrm{i}}$ & & & & 8,000 & 0,125 & 0,181 & 4,15 & \\
\hline $\begin{array}{c}\text { Summa } \\
\text { Thermal } \\
\text { insulance } \\
\text { (u) }\end{array}$ & & & & & $\begin{array}{l}0,692 \\
1,44\end{array}$ & 1,000 & 23,00 & \\
\hline \multicolumn{9}{|c|}{ S2 } \\
\hline$h_{a}$ & & & & 24,000 & 0,042 & 0,040 & 0,92 & \\
\hline $\begin{array}{l}\text { Porous } \\
\text { limestone }\end{array}$ & 0,15 & 1300 & 0,520 & 3,467 & 0,288 & 0,276 & 6,36 & 0,424 \\
\hline Brick wall & 0,44 & 1730 & 0,780 & 1,773 & 0,564 & 0,540 & 12,43 & 0,282 \\
\hline $\begin{array}{l}\text { Lime } \\
\text { plaster }\end{array}$ & 0,02 & 1650 & 0,810 & 40,500 & 0,025 & 0,024 & 0,54 & 0,272 \\
\hline & & & & 8,000 & 0,125 & 0,120 & 2,75 & \\
\hline $\begin{array}{c}\text { Summa } \\
\text { Thermal } \\
\text { insulance } \\
\text { (u) }\end{array}$ & & & & & $\begin{array}{l}1,044 \\
0,96\end{array}$ & 1,000 & 23,00 & \\
\hline
\end{tabular}




\section{Modeling}

It was supposed that the impact of urban heat island effect, the shelter of the thermal bridges and future climate change allow sand fly species to overwinter in heat-polluted environments. Three different models were built in order to investigate whether Budapest and its surroundings provide suitable environment in terms of climate for the six sand fly species. The studied species were assorted by their cold tolerance in three groups (Table 1.). There are three components used in the models: a., heat island effect (Eq. 1), b., the effect of thermal bridges, and c., the effect of the predicted climate change. In Method 1. only component a., was considered. In Method 2. components a., and b., (Eq. 2), and in Method 3. all the three components were considered (Eq. 3).

$$
\begin{gathered}
T_{1}=T_{0}-\Delta T_{U H I}+\Delta T_{a i r} \\
T_{2}=f_{T B}\left(T_{0}-\Delta T_{U H I}\right)+\Delta T_{a i r} \\
T_{3}=f_{T B}\left(T_{0}-\Delta T_{U H I}\right)-\Delta T_{F D}+\Delta T_{a i r}, \text { where }
\end{gathered}
$$

$\Delta T_{\text {air }}:$ difference of air and ground temperature

$\Delta T_{U H z}$ : temperature difference caused by urban heat island

$f_{T E}(T)$ : sheltering effect of the thermal bridges

$\Delta T_{F F}$ : temperature difference of the reference period and the future prediction

Conversion from ground temperature to air temperature (at $2 \mathrm{~m}$ height) was applied in all of the three methods based on averaged differences in six observation points in the studied domain (Lelovics, 2012). The observations were made in winter at night. The calculated difference $\left(1.84{ }^{\circ} \mathrm{C}\right)$ has the opposite sign to the three aforementioned temperature altering effects (the air temperature is greater than the ground temperature).

The effect of urban heat island was calculated by a script written in R for all the 4900 studied points. Our preliminary calculation showed that both second order polynomial regression and linear regression with major axis method are highly unstable for calculating the base temperature dependence of the volume of the urban heat island. Therefore simple averaging was done based on the 12 selected images. The maximum heat surplus of the urban heat island was $+4.10^{\circ} \mathrm{C}$.

The sheltering effect of the thermal bridges was calculated based on the measurements made on the spot S2. Linear regression was made, since the volume of the temperature difference showed correlation with the base temperature. The warming effect of the predicted climate change was approximated by averaging the warming in the 48 points of the domain. The value occurred to be $-14.36{ }^{\circ} \mathrm{C}$ in the reference period; $-10.28{ }^{\circ} \mathrm{C}$ in the prediction period, therefore $4.08{ }^{\circ} \mathrm{C}$ was subsequently used as the difference.

The result of the three methods in the case of the three groups was displayed by ESRI ArcGIS 10 software. The grid was interpolated by inverse distance weighted (IDW) method with power 2 and 12 neighboring points. The results were clustered between isotherms of the even integer numbers in the Celsius scale. Digital NUTS3 polygon borders were displayed to help orientation (GISCO 2013).

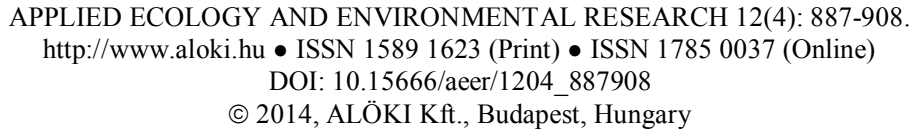




\section{Results}

\section{Differences in thermal behavior of the two spots}

Great difference was calculated between the thermal insulation capacities of the two wall structures containing the two spots S1 and S2. The wall containing S2 turned out to be $33 \%$ better insulator (u-value of 0.96 versus 1.44 ) than $\mathrm{S} 1$, which suggests that heat loss is more intensive in the case of spot S1. However, temperatures of the limestone surface were found to be higher in most of the cases: in $66.67 \%$ of the measured minimum temperatures and in $75 \%$ of the measured maximum temperatures. Moreover, strong correlations were found $\left(\mathrm{S} 1: \mathrm{y}=1.011 \mathrm{x}+3.765 ; \mathrm{R}^{2}=0.9785\right.$ and $\mathrm{S} 2: \mathrm{y}=0.824 \mathrm{x}$ $+4.715 ; \mathrm{R}^{2}=0.946$ ) between the minimum and the maximum temperatures of the thermal bridges - see Fig. 4. Different gradient and intersection of trend lines fitted on the measured values showed that the two thermal bridges behave differently due to the changes of the ambient temperature.

Moreover, regarding both the minimum and maximum temperature values, relative differences are higher in the colder period (rel. difference of minimum values: $1.48 \pm$ $1.26{ }^{\circ} \mathrm{C}$ and $3.02 \pm 1.07{ }^{\circ} \mathrm{C}$ for the maximum values) than in the milder period with higher temperature values (rel. difference of minimum values: $0.65 \pm 0.89{ }^{\circ} \mathrm{C}$ and $1.23 \pm 1.60{ }^{\circ} \mathrm{C}$ for the maximum values). According to the fitted linear trend this means a 3.88-3.59 ${ }^{\circ} \mathrm{C}$ permanent difference in the $10-(-15){ }^{\circ} \mathrm{C}$ interval for $\mathrm{S} 1$ and a $2.96-$ $7.35{ }^{\circ} \mathrm{C}$ difference in the $10-(-15){ }^{\circ} \mathrm{C}$ interval for the $\mathrm{S} 2-$ see the two trend lines moving away from each other in Fig. 4.

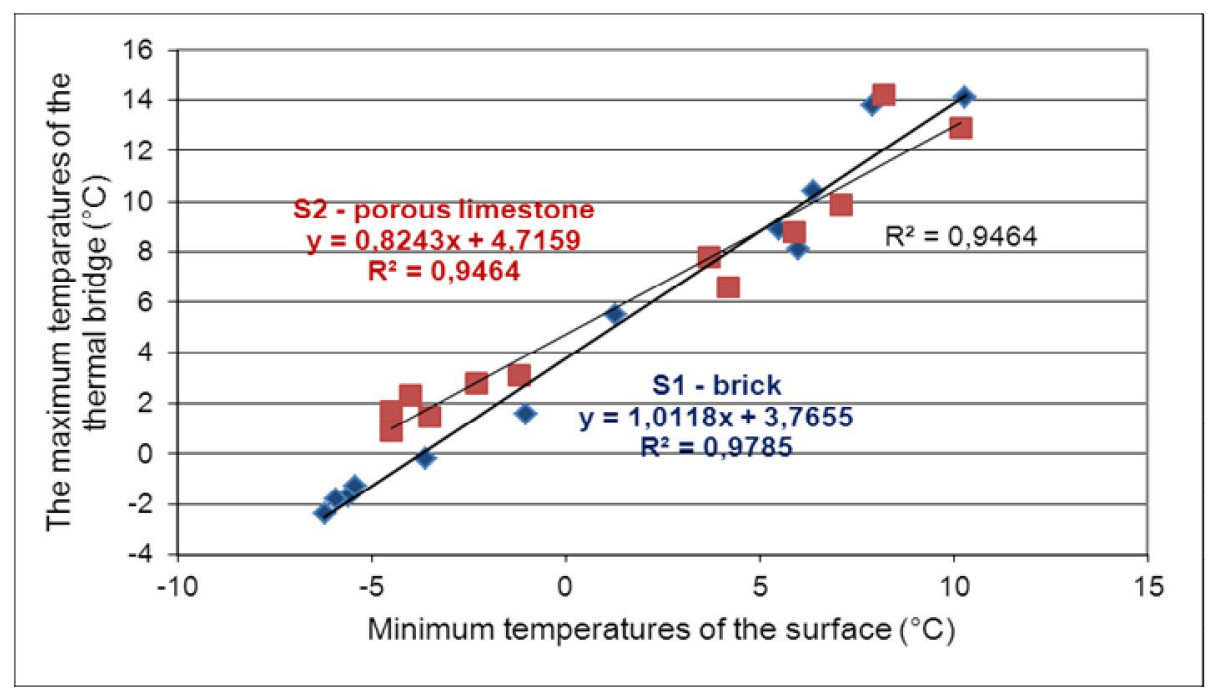

Figure 4. Correlation between the minimum and maximum surface temperatures measured on the two spots

Using the linear trends we calculated the expected maximum temperature of the thermal bridges according to the minimum temperatures of the surfaces. The intersection point of the two trend lines was calculated to be $\mathrm{P}\left(5.0688{ }^{\circ} \mathrm{C} ; 8.894{ }^{\circ} \mathrm{C}\right)$, which shows that, for the minimum temperatures lower than $\mathrm{x}=5.0688{ }^{\circ} \mathrm{C}$, the differences between the maximum and minimum temperatures measured on the spots will be higher for the limestone cover.

Secondly, the maximum surface temperatures were compared to the limits of the temperature tolerance of the different species, in order to evaluate the ambient minimum 
temperature limiting the survival of the Phlebotomus species - see Fig. 5. By calculating the first coordinates of the intersection points of the trend lines and the horizontal limits, the critical minimum temperatures were determined. It is noticeable that due to the calculated heat surplus of the thermal bridges, different sandfly species are able to tolerate environmental temperatures ranging from +1.60 (brick surface Phlebotomus ariasi) to $-12.61{ }^{\circ} \mathrm{C}$ (limestone surface - Phlebotomus mascittii, Phlebotomus neglectus, Phlebotomus papatasi and Phlebotomus perfiliewi).

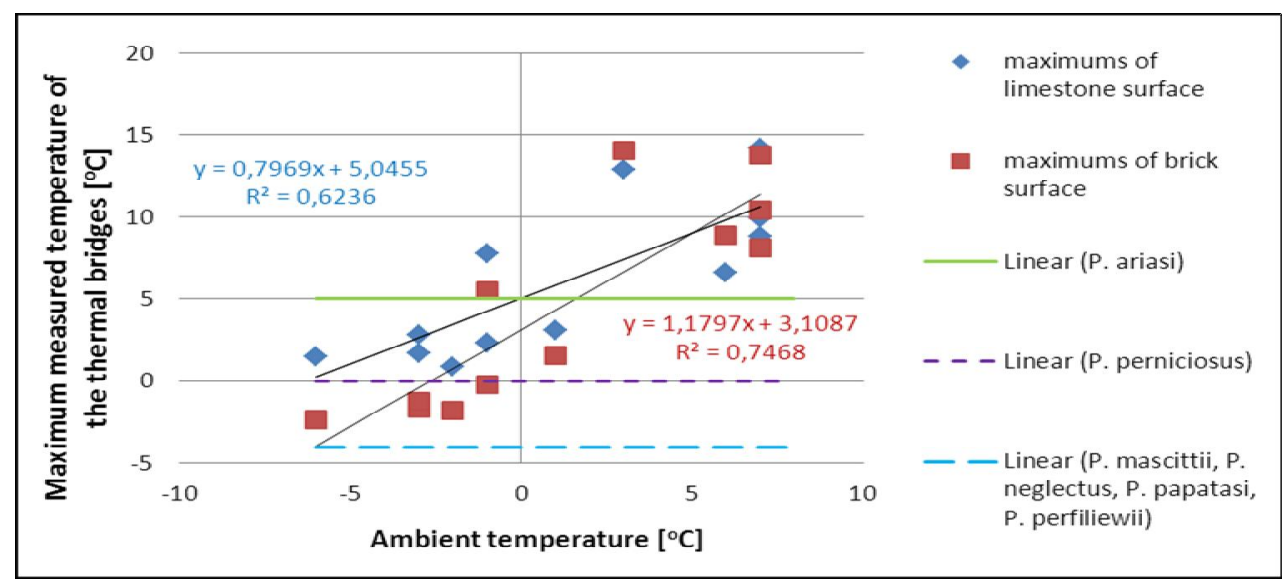

Figure 5. Correlation between the maximum surface temperatures measured on the two spots and the ambient temperature ( $S 2$ - blue dots; $S 1$ - red dots) with the minimum temperature tolerance of the sandfly species groups (marked with vertical coloured lines).

\section{Impact of urban heat emission on the potential distribution of sand flies}

The result of the linear regression based on the measures at spot S2 is shown in Eq.

$$
T_{\min }=0.1481 * T_{\max }-5.3280^{\circ} \mathrm{C}
$$

The descriptive statistics of the three methods in the case of the three studied groups was summarized in Table 3.

Table 3. Descriptive statistics of the three group (1: Phlebotomus ariasi, 2: Phlebotomus perniciosus, 3: Phlebotomus (Tr.) mascittii, Phlebotomus neglectus, Phlebotomus papatasi, Phlebotomus perfiliewi) and the three methods (specified in the text).

\begin{tabular}{c|c|c|c|c|c}
\hline$\left.{ }^{\circ} \mathbf{C}\right)$ & Minimum & Maximum & $\begin{array}{c}\text { Mean } \\
(\mathbf{a l l})\end{array}$ & $\begin{array}{c}\text { Mean (rural } \\
\text { only) }\end{array}$ & $\begin{array}{c}\text { Mean (urban } \\
\text { only) }\end{array}$ \\
\hline Method 1. (Group 1.) & 2,7250 & 9,4451 & 6,5981 & 6,8295 & 4,9017 \\
Method 1. (Group 2.) & $-2,2749$ & 4,4451 & 1,5981 & 1,8295 & $-0,0982$ \\
Method 1. (Group 3.) & $-6,2749$ & 0,4451 & $-2,4018$ & $-2,1704$ & $-4,0982$ \\
Method 2. (Group 1.) & $-2,4718$ & 5,2433 & 1,9747 & 2,2404 & 0,0271 \\
Method 2. (Group 2.) & $-8,2122$ & $-0,4970$ & $-3,7656$ & $-3,4999$ & $-5,7132$ \\
Method 2. (Group 3.) & $-12,8046$ & $-5,0893$ & $-8,3579$ & $-8,0922$ & $-10,3055$ \\
Method 3. (Group 1.) & $-6,5545$ & 1,1606 & $-2,1079$ & $-1,8422$ & $-4,0555$ \\
Method 3. (Group 2.) & $-12,295$ & $-4,5797$ & $-7,8483$ & $-7,5826$ & $-9,7959$ \\
Method 3. (Group 3.) & $-16,8873$ & $-9,1720$ & $-12,4407$ & $-12,1750$ & $-14,3882$ \\
\hline
\end{tabular}


The result of the GIS modeling can be seen in Fig. 6, Fig. 7 and Fig. 8.
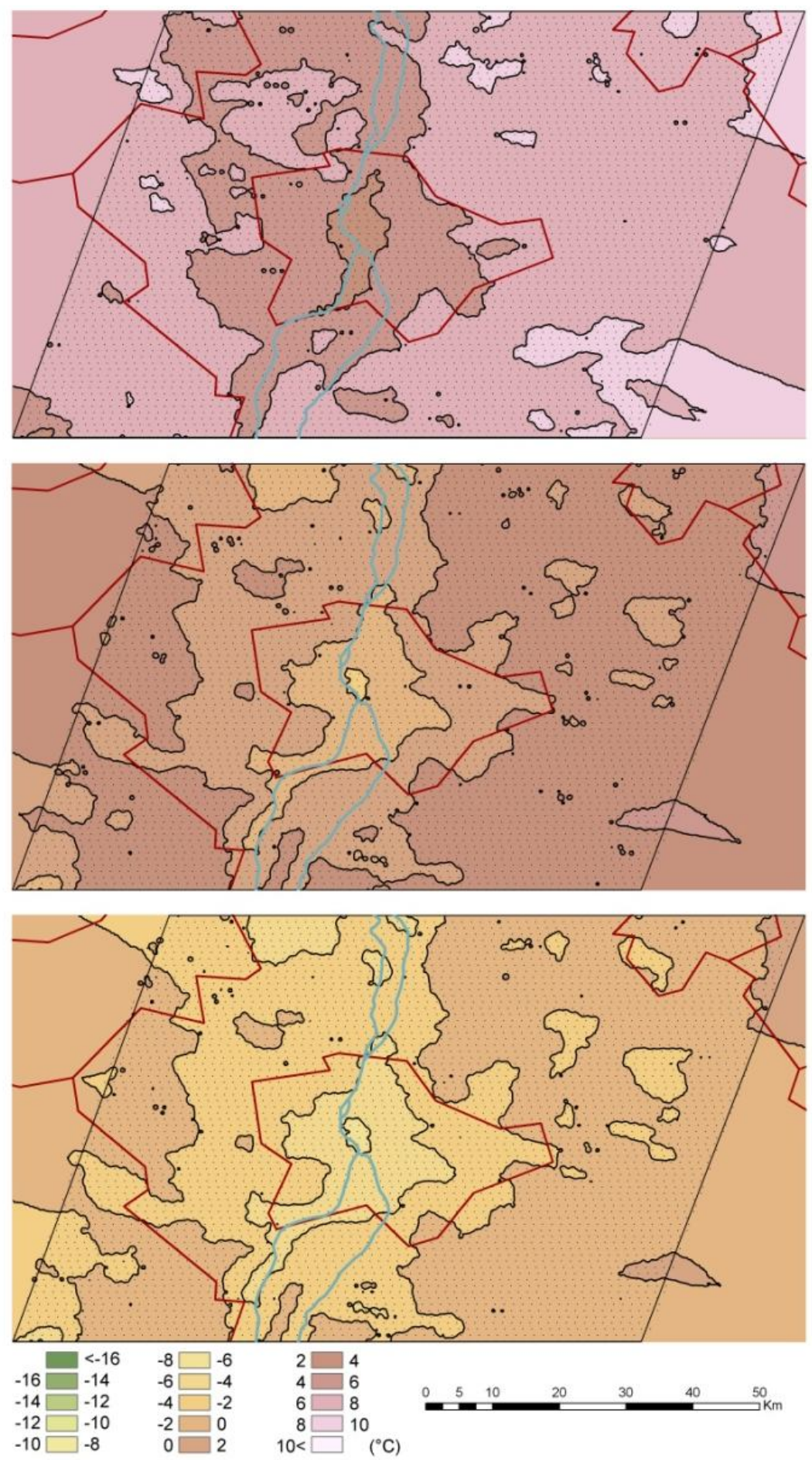

Figure 6. The average air temperature of the region which can be tolerated by Phlebotomus ariasi in a certain location with urban heat island (Method 1., upper image), with urban heat island and the sheltering effect of the thermal bridges (Method 2., middle image), and with urban heat island and the sheltering effect of the thermal bridges in the period of 2025-2050 (Method 3., lower image) 
The displayed temperature values mean the average air temperature of the region which can be tolerated by the species in a certain location in the case of the three methods.
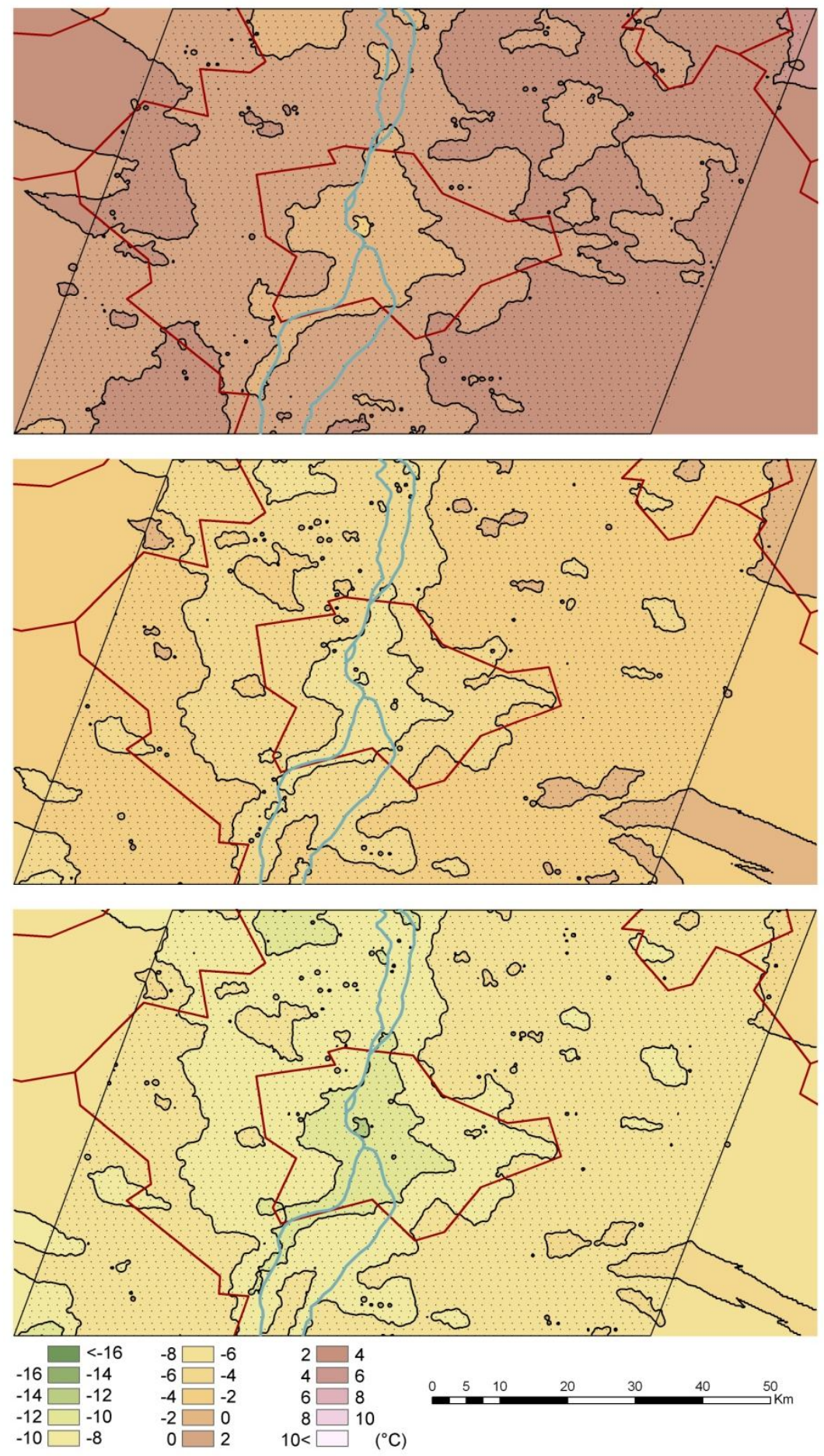

Figure 7. The average air temperature of the region which can be tolerated by Phlebotomus perniciosus in a certain location with urban heat island (Method 1., upper image), with urban heat island and the sheltering effect of the thermal bridges (Method 2., middle image), and with urban heat island and the sheltering effect of the thermal bridges in the period of 2025-2050

(Method 3., lower image) 

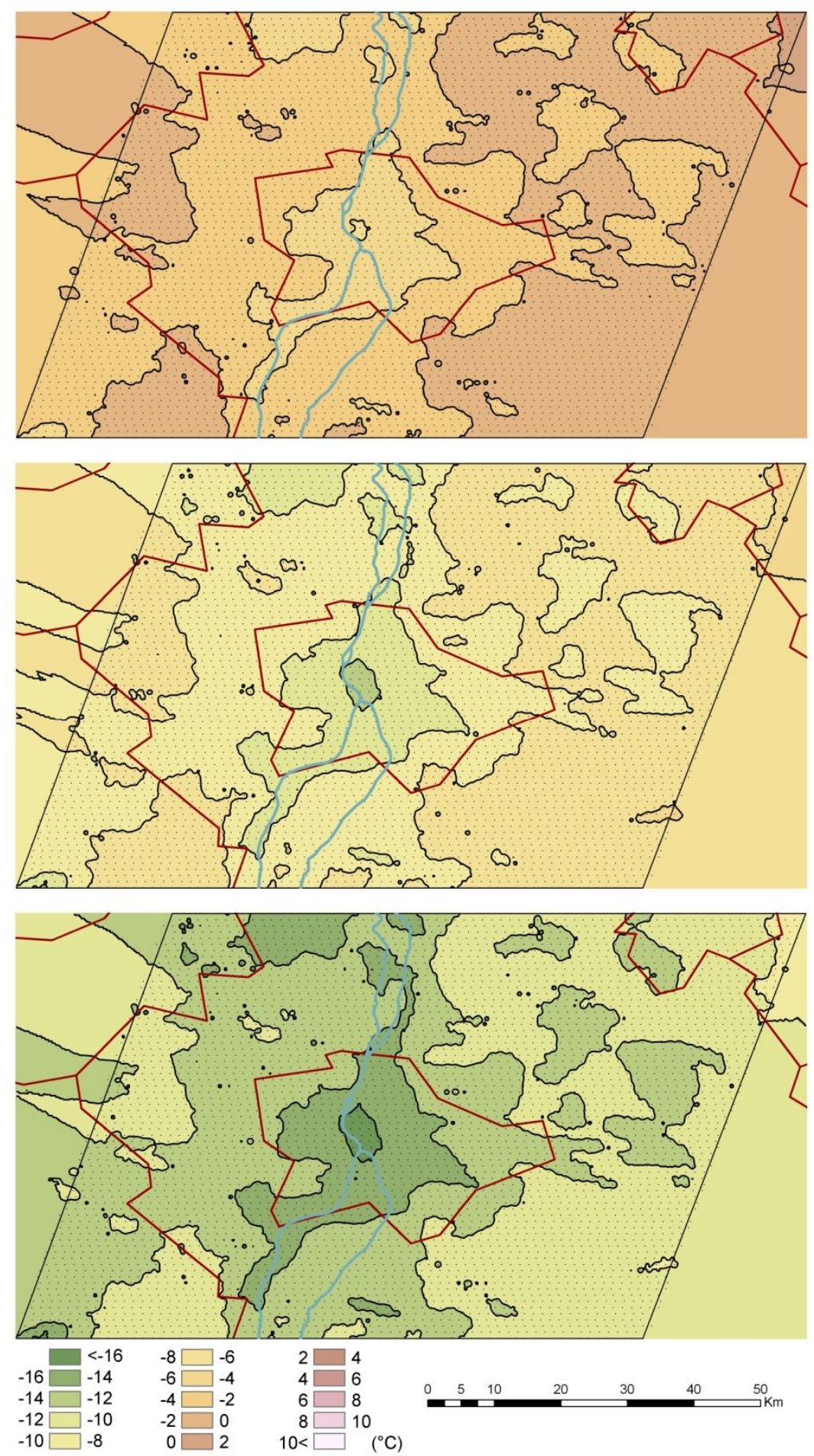

Figure 8. The average air temperature of the region which can be tolerated by Phlebotomus mascittii, Phlebotomus neglectus, Phlebotomus papatasi and Phlebotomus perfiliewi in a certain location with urban heat island (Method 1., upper image), with urban heat island and the sheltering effect of the thermal bridges (Method 2., middle image), and with urban heat island and the sheltering effect of the thermal bridges in the period of 2025-2050 (Method 3., lower image) 


\section{Discussion and future perspectives}

The recent occurrence of sandfly species (Phlebotomus neglectus, Phlebotomus mascittii) in the agglomeration of Budapest could not have been achieved without the tempering effect of the heat-polluted shelters, since the recent winter outdoor ambient temperatures of Budapest could not allow the outdoor overwintering of Phlebotomus species since the annual average minimum temperature of the surrounding areas of Budapest is between approximately -17.8 to $-15.0^{\circ} \mathrm{C}$. According to our model results, only Method 3 predicts possible overwintering, and only for the Phlebotomus mascittii, Phlebotomus neglectus in the non-heated, non-protected environments. Since the average annual minimum temperature is about -15 to $-12.2{ }^{\circ} \mathrm{C}$, according to the Method 1 (using only the present effect of the urban heat island) at the observation point of these species in Törökbálint (in the agglomeration of Budapest), Phlebotomus mascittii, Phlebotomus neglectus can overwinter only in milder shelters which have a +10 to +13 ${ }^{\circ} \mathrm{C}$ surplus compared to the external environment. Using Method 2 (which operates with both the urban heat effect and thermal bridges), Phlebotomus mascittii, Phlebotomus neglectus can overwinter in warmer shelters where the temperature is warmer by 0.8 to $5{ }^{\circ} \mathrm{C}$ than the external environment. This means that the observed two sandflies can overwinter only in protected or indoor environments in the studied area. The winter hardiness of the species of the other two groups is less pronounced.

According to the in situ measurements, the maximum surface temperatures were 3 $7{ }^{\circ} \mathrm{C}$ higher than the ambient temperature due to the effect of the thermal bridges at the studied points. Moreover, temperatures of the limestone surface were found to be higher in most of the cases: in $66.67 \%$ of the measured minimum temperatures and in $75 \%$ of the measured maximum temperatures. The first reason for the higher surface temperatures of the limestone surface compared to the brick covering in colder weather is that the latter one is a wetted surface. Since the specific heat of the water is very high $\left(4.2 \mathrm{~kJ} / \mathrm{kg}{ }^{\circ} \mathrm{C}\right)$, a wetted material cannot follow the changes of the environmental temperature as fast as a dry material. Moreover, the higher surface temperature of the limestone surface can also be contributed to the lower thermal conductivity value of the limestone $\left(3,467 \mathrm{~W} / \mathrm{m}^{2} \mathrm{~K}\right)$ compared to the brick $\left(7,750 \mathrm{~W} / \mathrm{m}^{2} \mathrm{~K}\right)$, and the overall better thermal insulance value of the limestone-covered wall. Lower thermal conductivity means higher specific heat, thus higher heat capacity. The higher heat capacity of the limestone covered wall due to the higher u-value means that limestone adapts to the changes of the environmental temperature much slower than brick. Moreover, with decreasing the environmental temperature, the limestone cover has a larger amount of heat support from the backing wall due to its higher heat capacity, which slows down the temperature decrease of the covering material. The correlation was found to be stronger between the minimum and maximum temperatures of the surfaces, than between the maximum surface temperatures and the ambient temperatures. This result further indicates that the two wall structures show a high inertia towards changes of the ambient temperature.

The above mentioned results showed that factors, for instance water-content and type of the material highly affect the intensity of thermal bridges. The flora and the microbial math of the studied wet brick thermal bridge (S1) showed that due to the leaving gutter, organic matter accumulation is observable in the cracks and in the join gaps, which is essential for the potential colonization of sand fly larvae. Below $5{ }^{\circ} \mathrm{C}$, the surface temperature of the wetter brick surface (S1) is lower than the surface temperature of the limestone (S2), maybe due to the evaporation of the water. In this comparison, the

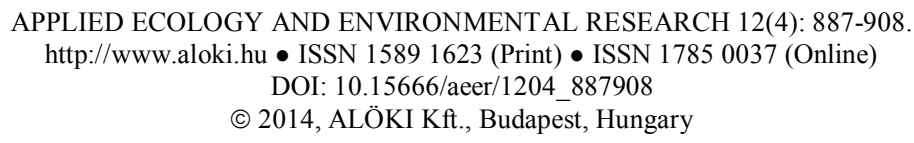


limestone surface seems to be milder, but since Phlebotomus larvae prefer wet mats and high air vapor-content, our opinion is that wetted bricks provide (as well as wetted nonporous, dense stone surfaces, concrete, etc.) a more adequate basis for modeling and predictions. However, thermal bridges in a wall structure with high heat capacity, thus high thermal insulation property, covered with well-insulating materials (for example porous stone materials: tuffs, sandstone and limestone) can provide high and permanent heat surplus even in the case of sudden falls of temperature.

The heat island effect of Budapest is notable and can exceed or can be as important as the minimum temperature moderating the effect of thermal bridges. We found that any scale of the thermal pollution - as the local microclimate-moderating thermal bridges or the mesoclimate moderating heat island effect - can highly change the original outdoor climate patterns. Our findings are in accordance with those results of Révész (2008) that the climate change in Hungary may cause serious public health and veterinary problems.

As Phlebotomus species have a wider distribution area than leishmaniasis itself, the expected future migration of sand flies due to climate change does not imply the same spread of the disease into the Northern regions of Europe. This contradicts with the observation in Hungary that geographical occurrence of canine leishmaniasis and the distribution of the potential vector Phlebotomus species of Leishmania infantum is nearly the same, except for the area of the Hungarian capital (Tánczos, 2012).

Our results suggest that the heat island effect of the capital and its agglomeration can explain the observed isolated, most Northern presence of some Phlebotomus species, while anthropogenic heat pollution (e.g. in the case of thermal bridges and cracks, fissures in the walls) can create the conditions for winter survival for sand flies. It is important to note that the importance of these isolated Phlebotomus populations can play very important role as the transmitters of Leishmania parasites to human beings, since more than 2.2 million people live in Paris and about 1.7 million in Budapest and with the commuters of the agglomerations the affected population can be 2-3 times higher.

It is important to emphasize that the future population, the structure of the city, the isolation techniques and the matter of energy production will probably not be the same some decades later.

\section{Conclusions and adaptation strategies}

Regarding the fact that the agglomeration of Budapest in the Carpathian Basin is the most Northern and isolated occurrence of the above mentioned species, it is plausible that sandflies can overwinter in heat polluted refugees. These refugees can be garages, unheated outbuildings, major cracks in the wall and protected surfaces of thermal bridges, as well. The highly populated Northern cities in the temperate areas are candidates to become the most Northern habitants of Phlebotomus species, and maybe that of leishmaniasis due to urban heat pollution. It is plausible that anthropogenic heat emission and the high domestic dog population can be the main causes of these distant, but existing distributions from the continuous endemic areas. In the further planning of the cities, several strategies should be taken into consideration, for instance reduction, or at least mitigation of the overwintering suitability for sandfly species by decreasing human heat emission. The adequate and modest use of the renewable energy sources may also provide a mitigation chance (Raghuvanshi and Chandra, 2008). 
This purpose may be achieved by opening new wind tunnels, increasing the area of green spaces (green roofs, parks instead of parking places) and increasing the efficiency of thermal insulation of buildings.

Acknowledgements. The authors would like to express their gratitude to Borbála Vető, Enikő Lelovics, Csaba Torma, János Unger, and András Béla Oláh for advices they gave and the data they have supported. The research was supported by the projects TÁMOP-4.2.1/B-09/1/KMR-2010-0005, TÁMOP4.2.2.A-11/1/KONV, ÚMFT TÁMOP-4.2.1/B-09/1/KMR-2010-0002, TÁMOP-4.2.2/B-10/1-2010-0009, and TÁMOP-4.2.2.A-11/1/KONV-2012-0064.

\section{REFERENCES}

[1] Ascione, R., Gradoni, L., \& Maroli, M. (1996). Studio eco-epidemiologico su Phlebotomus perniciosus in focolai di leishmaniosi viscerale della Campania. Parassitologia, 38, 495-500.

[2] Banfield, J. F., Barker, W. W., Welch, S. A., \& Taunton, A. (1999). Biological impact on mineral dissolution: application of the lichen model to understanding mineral weathering in the rhizosphere. Proceedings of the National Academy of Sciences, 96(7), 3404-3411.

[3] Bartholy, J., Pongrácz, R., Lelovics, E., Dezső, Zs. (2009): Comparison of urban heat island effect using ground-based and satellite measurements. Acta Climatologica et Chorologica, Universitatis Szegediensis, 42-43: 7-15.

[4] Bede-Fazekas, Á. (2012): Methods of modelling the future shift of the so called Moeszline. Applied Ecology and Environmental Research, 10(2): 141-156.

[5] Bettini, S., Contini., C., Atzeni, M.C., Tocco, G. (1986a) Leishmaniasis in Sardinia. I. Observations on a larval breeding site of Phlebotomusperniciosus, Phlebotomusperfiliewiperfiliewi and Sergentomyiaminuta (Diptera: Psychodidae) in the canine leishmaniasis focus of Soleminis (Cagliari). Ann Trop Med Parasitol, 80(3): 30715.

[6] Bettini, S., Gramiccia, M., Gradoni, L., Atzeni, M. C. (1986b). Leishmaniasis in Sardinia: II. Natural infection of Phlebotomus perniciosus Newstead 1911, by Leishmania infantum Nicolle 1908, in the province of Cagliari. Transactions of the Royal Society of Tropical Medicine and Hygiene, 80(3), 458-459.

[7] Bettini, S., Melis, P. (1988). Leishmaniasis in Sardinia. III. Soil analysis of a breeding site of three species of sandflies. Medical and Veterinary Entomology, 2(1), 67-71.

[8] Bettini S., Maroli M., Loddo S., Atzeni C. (1991). Leishmaniasis in Sardinia: VI. Further observations on the biology of Phlebotomus perniciosus Newstead, 1911, Phlebotomus perfiliewi Parrot, 1930, and Sergentomiya minuta Rondani, 1843, (Diptera: Psychodidae). Bull Soc Vector Ecol, 16(2): 230-244.

[9] Binggeli, C. (2010). Building Systems for Interior Designers. 2nd. Hoboken, NJ: John Wiley \& Sons, Inc.] Building Systems for Interior Designers

[10] Bradley, C. A., Altizer, S. (2007). Urbanization and the ecology of wildlife diseases. TRENDS in Ecology and Evolution, 22(2), 95-102.

[11] Biocca, E., Coluzzi, A., Costantini, R. (1977). sull'attuale distribuzione dei flebotomi italiani e su alcuni caratteri morfologici differenziali tra le specie del sottogenere Phlebotomus.Parassitologia, 19:19-37.

[12] Cortes, S., Afonso, M. O., Alves-Pires, C., Campino, L. (2007). Stray dogs and leishmaniasis in urban areas, Portugal. Emerging Infectious Diseases, 13(9), 1431.

[13] Dantas-Torres, F., Latrofa, M. S., Otranto, D. (2010). Occurrence and genetic variability of Phlebotomus papatasi in an urban area of southern Italy. Parasites \& vectors, 3, 77-77. 
Trájer et al.: The combined impact of urban heat island, thermal bridge effect of buildings and future climate change on the potential overwintering of Phlebotomus species in a Central European metropolis -906 -

[14] Dantas-Torres, F., Brito, M. E. F. D., Brandão-Filho, S. P. (2006). Seroepidemiological survey on canine leishmaniasis among dogs from an urban area of Brazil. Veterinary parasitology, 140(1), 54-60.

[15] Drever, J. I., Stillings, L. L. (1997). The role of organic acids in mineral weathering. Colloids and Surfaces A: Physicochemical and Engineering Aspects, 120(1), 167-181.

[16] Garamvölgyi, Á., Hufnagel, L. (2013). Impacts of climate change on vegetation distribution. No. 1: Climate change induced vegetation shifts in the palearctic region. Applied Ecology and Environmental Research, 11(1), 79-122.

[17] Gimesi, L., Homoródi, R., Hirka, A., Szaboki, C., Hufnagel, L. (2012). The effect of climate change on the phenology of moth abundance and diversity. Applied Ecology and Environmental Research, 10(3), 349-363.

[18] Gutro, R., Ramanujan, K, Closs, J. (2002): Science writers' guide to Aqua. - Goddard Space Flight Center, Greenbelt, Maryland.

[19] Hanson, W. J. (1961). The breeding places of Phlebotomus in Panama (Diptera, Psychodidae). Annals of the Entomological Society of America, 54(3), 317-322.

[20] Heinrich, D., Fahnert, R., Hergt, M. (2006). Dtv-Atlas Erde: physische Geographie; mit 147 Abbildungseiten in Farbe. Dt. Taschenbuch-Verlag.

[21] Hufnagel, L., Gaál, M. (2005). Seasonal dynamic pattern analysis in service of climate change research. A methodical case-study-monitoring and simulation based on an aquatic insect community. Applied Ecology and Environmental Research, 3(1), 79-132.

[22] Kamhawi, S., Abdel-Hafez, S. K., Molyneux, D. H. (1991). Urbanization--how does it affect the behaviour of sandflies?. Parassitologia, 33, 299.

[23] Killick-Kendrick, R. 1987a. Breeding places of Phlebotomus ariasi in the cevennes focus ofleishmaniasis in the south of France. Parassitologia. 29: 181-91.

[24] Killick-Kendrick, R., M. Killick-Kendrick. 1987b. The laboratory colonization of Phlebotomusariasi (Diptera, Psychodidae). Ann Parasitol Hum Comp. 62: 354-356.

[25] Killick-Kendrick, R. (1999). The biology and control of phlebotomine sand flies. Clinics in dermatology, 17(3), 279.

[26] Killick-Kendrick, R. 1990. Phlebotomine vectors of the leishmaniases: a review. Medical andVeterinary Entomolog. 4: 1-24.

[27] Killick-Kendrick, R., Rioux, J. A., Bailly, M., Guy, M. W., Wilkes, T. J., Guy, F. M., Guilvard, E. (1984). Ecology of leishmaniasis in the south of France. 20. Dispersal of Phlebotomus ariasi Tonnoir, 1921 as a factor in the spread of visceral leishmaniasis in the Cévennes. Annales de parasitologie humaine et comparée, 59(6), 555.

[28] Kim, Y. H., \&Baik, J. J. (2004). Daily maximum urban heat island intensity in large cities of Korea. Theoretical and Applied Climatology, 79(3-4), 151-164.

[29] Kuhn, K. G. (1999). Global warming and leishmaniasis in Italy. Bull Trop Med Int Health, 7(1), 1-2.

[30] Lelovics, E., Pongrácz, R., Bartholy,J., Dezső, Zs. (2012): Budapesti városi hősziget hatás elemzése műholdas és felszíni mérések alapján. In: Nyári, D. (ed.): Kockázat konfliktus - kihívás. A VI. Magyar Földrajzi Konferencia, a MERIEXWA nyitókonferenciája és a Geográfus Doktoranduszok Országos Konferenciájának Tanulmánykötete. - Szegedi Tudományegyetem, Szeged.

[31] Lelovics, E. (2012): Műholdas és állomási méréseken alapuló városi hősziget vizsgálat Budapest térségére. - Thesis. Eötvös Loránd University, Department of Meteorology.

[32] Léger, N., J. Depaquit, H. Ferté, J.A. Rioux, J.C. Gantier, M. Gramiccia, A. Ludovisi, A. Michaelides, N. Christophi, P. Economides (2000): Phlebotomine sand flies (Diptera: Psychodidae) of the isle of Cyprus. II - isolation and typing of Leishmania (Leishmania infantum Nicolle, 1908 (zymodeme MOM 1) from Phlebotomus (Larrouius) tobbi Adler and Theodor, 1930. - Parasite 7: 143-146.

[33] Lindgren, E., Naucke, T., Menne, B. (2004). Climate variability and visceral leishmaniasis in Europe. Report of the scientific working group on leishmaniasis. WHO, Geneva. Document TDR/SWG/04, 88-92.

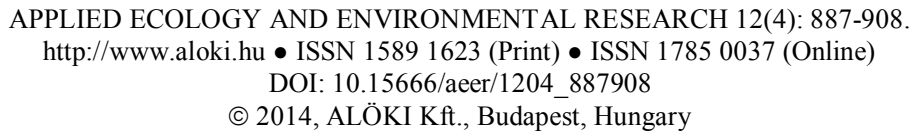


Trájer et al.: The combined impact of urban heat island, thermal bridge effect of buildings and future climate change on the potential overwintering of Phlebotomus species in a Central European metropolis -907 -

[34] Loughnan, Frederick Charles. "Chemical weathering of the silicate minerals." (1969).

[35] Maroli, M., \& Bettini, S. (1977). Leishmaniasis in Tuscany (Italy):(I) An investigation on phlebotomine sandflies in Grosseto Province. Transactions of the Royal Society of Tropical Medicine and Hygiene 71(4), 315-321.

[36] Maroli, M., Bigliocchi, F., Khoury, C.(1994) - I flebotomi in Italia: osservazioni sulla distribuzione e metodi di cattura. Parassitologia, 36: 251-264.

[37] Maroli, M., Khoury, C. (1998) Leishmaniasis vectors in Italy (1998). G. Ital. Med. Trop., 3:67-72

[38] Marty, P., Izri, A., Ozon, C., Haas, P., Rosenthal, E., Del Giudice, P., ... \& Le Fichoux, Y. (2007). A century of leishmaniasis in Alpes-Maritimes, France. Annals of tropical medicine and parasitology 101(7), 563-574.

[39] Minter, D. M. (1989.) The leishmaniasis. In: Geographical distribution of arthropodborne diseases and their principal vectors. WHO, Geneva (document WHO/VBC/89.967)

[40] Moncaz A, Faiman R, Kirstein O, Warburg A (2012) Breeding Sites of Phlebotomussergenti, the Sand Fly Vector of Cutaneous Leishmaniasis in the Judean Desert. PLoSNegl Trop Dis 6(7): e1725.

[41] Naderer, T., Ellis, M. A., Sernee, M. F., De Souza, D. P., Curtis, J., Handman, E., McConville, M. J. (2006). Virulence of Leishmania major in macrophages and mice requires the gluconeogenic enzyme fructose-1, 6-bisphosphatase. Proceedings of the National Academy of Sciences, 103(14), 5502-5507.

[42] Naucke, T. J., Pesson, B. 2000. Presence of Phlebotomus (TransPhlebotomus) mascittii Grassi, 1908 (Diptera: Psychodidae) in Germany. Parasitology research, 86(4), 335-336.

[43] Naucke TJ, Schmitt C (2004) Is leishmaniasis becoming endemic in Germany? Int J Microbiol 293(Suppl. 37):179-181

[44] Naucke, T.J. 2002. Leishmaniosis, a tropical disease and its vectors (DipteraPsychodidae, Phlebotominae) in Central Europe. Denisia. 6: 163-178.

[45] Naucke, T, 2007. Leishmaniasis - entering Germany. Tierarztl Umsch 62, 495-500.

[46] Oke, T. R. (1973). City size and the urban heat island. Atmospheric Environment (1967), 7(8), 769-779.

[47] Oshaghi, M. A., Ravasan, N. M., Javadian, E., Rassi, Y., Sadraei, J., Enayati, A. A., Vatandoost, H., Zare, Z., Emami, S. N. (2009). Application of predictive degree day model for field development of sandfly vectors of visceral leishmaniasis in northwest of Iran. J Vector Borne Dis, 46(4), 247-255.

[48] Pongrácz, R., Bartholy, J., Miklós, E. (2011). Analysis of projected climate change for Hungary using ENSEMBLES simulations. Applied Ecology and Environmental Research, 9(4), 387-398.

[49] Pongrácz, R., Bartholy, J., Dezső, Zs. (2006). Remotely sensed thermal information applied to urban climate analysis. Advances in Space Research, 37(12), 2191-2196

[50] Raghuvanshi, S. P., Chandra, A. R. A. (2008). Renewable energy resources for climate change mitigation. Applied Ecology and Environmental Research, 6(4), 15-27.

[51] Ready, P. D. (2010). Leishmaniasis emergence in Europe. Euro Surveill, 15(10), 19505.

[52] Révész, A. (2008). Stochastic behaviour of heat waves and temperature in Hungary. Applied Ecology and Environmental Research, 6(4), 85-100.

[53] Santamouris, M. (2001). Heat-island effect (Vol. 402). James \& James: London.

[54] Shaw, S.E., A. Lerga, S. Williams (2003.) Review of exotic infectious diseases in small animals entering the United Kingdom from aboard diagnosed by PCR. Vet. Rec. 152: 176-77.

[55] Shochat, E., Warren, P. S., Faeth, S. H., McIntyre, N. E., \& Hope, D. (2006). From patterns to emerging processes in mechanistic urban ecology. Trends in Ecology \& Evolution, 21(4), 186-191.

[56] Shortt, H. E., Smith, R. O. A., Swaminath, C. S. (1930). The Breeding in Nature of Phlebotomus argentipes, Bulletin of Entomological Research, 21(03), 269-271.

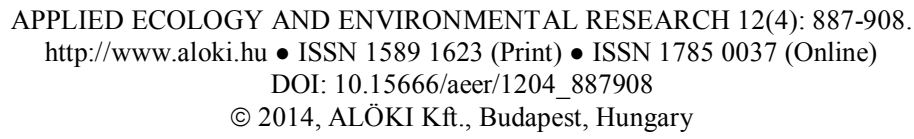


[57] Singh, K. V. (1999). Studies on the role of climatological factors in the distribution of phlebotomine sandflies (Diptera: Psychodidae) in semi-arid areas of Rajasthan, India. Journal of arid environments, 42(1), 43-48.

[58] Szentkirályi Zs., Lörincz F. (1932): Phlebotomus csípése által okozott különös dermatosisról. Orv. Hetil., 76: 665-668.

[59] Tánczos, B., N. Balogh, L. Király, I. Biksi, L. Szeredi, M. Gyurkovsky, A. Scalone, E. Fiorentino, M. Gramiccia, R. Farkas. (2012a), First record of autochthonous canineleishmaniasis in Hungary. Vector Borne Zoonotic Dis.12: 588-594.

[60] Tánczos 2012): PhD thesis. Szent István University Állatorvos-tudományi Doktori Iskola A kutya leishmaniózis és a parazita vektorainak vizsgálata Magyarországon Tánczos Balázs PhD értekezés Budapest 2012http://phd.univet.hu/lapok/TanczosB-D-H.pdf

[61] Tarallo, V. D., Dantas-Torres, F., Lia, R. P., \& Otranto, D. (2010). Phlebotomine sand fly population dynamics in a leishmaniasis endemic peri-urban area in southern Italy. Actatropica, 116(3), 227-234.

[62] Török, Á. (2002). Oolitic limestone in a polluted atmospheric environment in Budapest: weathering phenomena and alterations in physical properties. Geological Society, London, Special Publications 205(1), 363-379.

[63] Trájer, A.J., Bede-Fazekas, Á., Hufnagel, L., Horváth, L., Bobvos, J., Páldy, A. (2013). The effect of climate change on the potential distribution of the European Phlebotomus species. Applied Ecology and Environmental Research, 11(2): 189-208.

[64] Tselentis, Y., Gikas, A., Chaniotis, B. (1994). Kala-azar in Athens basin. Lancet 343 : 1635.

[65] Vanni, V., (1940.) Transmission and Prophylaxis of Cutaneous Leishmaniasis in Italy.Epidemiologia, trasmissione e profilassidellaLeishmaniosicutanea in Italia. Journal Ann. d'Igiene. Vol. 50 No. 2 pp.49-58 pp.

[66] Vogel, J. C., Rumsey, F. J., Russell, S. J., Cox, C. J., Holmes, J. S., Bujnoch, W.,Gibby, M. (1999). Genetic structure, reproductive biology and ecology of isolated populations of Asplenium csikii (Aspleniaceae, Pteridophyta). Heredity, 83(5), 604-612.

[67] World Health Organization WHO/LEISH/200.42, Leishmania/HIV Co-Infection in Southwestern Europe 1990-98: Retrospective Analysis of 965 Cases, 2000.

[68] WHO. 1984. The leishmaniases: report of an expert committee. WHO Tech Rep Ser 701: $1-140$.

[69] Yuval, B., Warburg, A., Schlein, Y. (1988). Leishmaniasis in the Jordan Valley. V. Dispersal characteristics of the sandfly Phlebotomus papatasi. Medical and Veterinary Entomology 2(4), 391-395. 